\title{
Exploring Socio-cultural Impacts of Ecotourism in the Annapurna Conservation Area, Nepal
}

\author{
Dr. Kishan Datta Bhatta ${ }^{1}$ \\ ${ }^{1}$ Dean and Associate Professor, Faculty of Engineering, Farwestern University, Nepal. \\ Email:dbkishan76@gmail.com
}

\begin{abstract}
:
Ecotourism is supposed to be culturally respectful and an agent to enhance indigenous values, culture and heritage conservation through ethical and responsible approach of development. Acknowledging its potential benefits, developing countries like Nepal have promoted ecotourism as a benign and alternative strategy to attract foreign capital particularly by showing indigenous culture, heritage and environmental resources to the tourists. However, in reality, ecotourism has also demonstrated its short-comings that have caused severe environmental damage and socio-cultural problems. In this regard, by adopting multiple techniques of data collection such as survey with households, interview with key informants, participant observation and archival study, this paper examines the role of ecotourism in the conservation of local culture and heritage, and explores the perceived socio-cultural impacts of ecotourism development in the Annapurna Sanctuary Trail in Annapurna region. Research Findings reveal that ecotourism has induced both positive and negative consequences on the local culture and social life. On one hand, social facilities and infrastructure such as road, school, health post, drinking water, and telecommunication have been improved in the settlements along the trail. On the other hand, local culture, traditions and architectural heritage have been threatened by the tourism development. The key objective of ecotourism i.e. conservation of local heritage and culture, is not fully achieved, however local people perceived significant benefits in terms of conservation of biodiversity and economic benefits. The lack of control on the construction of private buildings, and no specific attention on the vernacular architecture, and local cultural practices has pushed communities towards crisis of cultural identity. It recommends to the relevant stakeholders, specifically the government, for adopting comprehensive policies of ecotourism development particularly to promote cultural heritage conservation and sustainability in the region.
\end{abstract}

Keywords: Ecotourism, Socio-cultural impacts, Community, Settlements, Annapurna Sanctuary Trail

\section{Introduction:}

In this $21^{\text {st }}$ century, the advancement in science and technology, globalization of capitalism, and increase in populations and their movement have significantly helped tourism to develop into one of the world's largest and fastest-growing industries. Tourism has become a global phenomenon, and demand for leisure time and travel is increasing day by day, and will be continued in future. It is because the household income in emerging economies is rising and consequently the demand for travel is also increasing. It is a key provider of jobs, a leading industry in service sector at global level, and a significant generator of foreign exchange at the national level. According to World Travel and Tourism Council (WTTC, 2019), the travel and tourism has contributed to $10.4 \%$ of the total GDP and generated 319 million jobs ( 1 in 10 jobs) in 2018.

Given the exponential increase in number of international tourists, and their potential contribution to foreign exchange earnings and employment opportunities to the people; alternative approaches to tourism such as ecotourism has been extensively promoted in the developing countries mainly to alleviate rural poverty and achieve overall sustainable 
development goals. As a result, ecotourism is expanding rapidly and penetrating into the rural settlements and the protected areas (Lacher \& Nepal, 2010). Ecotourism, as a subset of sustainable tourism, is increasingly viewed as a green strategy to achieve sustainable development goals. Many developing countries are committed towards ecotourism to receive economic growth through responsible use of natural and cultural resources (Duffy, 2002). Lindberg et. al (1996) argued that ecotourism could provide benefits to local communities if they support conservation activities. It adopts an approach similar to the sustainable development, and is positively and significantly correlated with each other.

Situated in the southern part of Asia, Nepal, the Himalayan Shangri-La, is a landlocked country between two rapidly developing economies India and China. Nepal exhibits immense diversity in geography, natural setting and culture, and has a comparative advantage for tourism development. The number of tourist arrival in 2018 is 1173072 and the average length of stay is 12.4 days (MoCTCA, 2019). According to WTTC (2019), the travel and tourism has contributed $7.9 \%$ of the total economy of Nepal in 2018 (i.e. the total GDP contribution is USD 2,225.8 million). Similarly, it has generated 1051000 jobs (i.e. 6.7\% of total employment). India and China are the major tourist markets for Nepal. In 2018, they contributed about $16 \%$ and $12 \%$ of total inbound tourist arrivals in Nepal respectively.

Protected areas (PAs) are the most popular tourist destinations of Nepal specifically for trekking, mountaineering, rafting and exploring wildlife and diverse indigenous culture. There are 20 PAs where more than $40 \%$ of the international tourists in Nepal prefer to visit every year (MoCTCA, 2011). The world's most famous trekking trails such as Annapurna-Trail is also situated within PA namely Annapurna Conservation Area (ACA). As the large numbers of indigenous people are living in or around the PAs, rapid growth of tourism has affected their way of life, local heritage, economy and environment. With more than six decades of tourism development, several settlements in and around the PAs (the major tourist destinations) have not only experienced transformation in terms of land use, shape and size but also undergone through significant economic, socio-cultural and environmental changes (Nepal, 2003, Nyaupane \& Thapa, 2004). Studies reveal that tourism development in PAs have actually induced problems of environmental degradation, waste generation, pollution, and loss of socio-cultural values, tradition and heritage (Gurung,1998;Sharma,1998;Nepal,2003;Nyaupane \& Thapa,2004). In this regard, this paper highlights on the role of ecotourism in promoting conservation of local culture and heritage and explore the community perceptions towards socio-cultural impacts of ecotourism with specific reference to the case of Annapurna Sanctuary Trail in the Annapurna Conservation Area (ACA) in Nepal. It highlights on the socio-cultural impacts of ecotourism and critically argued whether local culture and heritage has been preserved or deteriorated with the growth of tourism in AST.

\section{Ecotourism: Theoretical Definitions}

Ecotourism, a highly-contested concept and strategy, is frequently adopted in developing countries as a pro-poor, sustainable pathway for local communities to improve their livelihoods (Kiss, 2004; Das and Chatterjee, 2015; Montes and Kafley, 2019). The concept of ecotourism has its roots deepen in the environmental movement during the 1970s and 1980s (Honey, 1999; Orams, 1995). Ceballos-Lascurain defined ecotourism as "environmentally responsible travel 
and visitation to relatively undisturbed natural areas, in order to enjoy and appreciate nature (and any accompanying cultural features- both past and present) that promotes conservation, has low negative visitor impact, and provides for beneficially active socio-economic involvements of local populations" (Blamey, 2001, p.5). This is one of the first formal and commonly accepted definitions of ecotourism which not only stresses on what is done in the destinations (e.g. study, admire, and enjoy nature and culture) but also suggests where it is done (relatively undisturbed areas), who does it (person who believes in value of nature, society and culture) and how they do it (low negative impacts, non-consumptive, involvements of local populations). It reveals nature orientation and sensitive ethic both ecologically and culturally. It is therefore a "responsible travel to natural areas that conserves the environment and sustains the well-being of local people and involves interpretation and education" (TIES, 2015). This concept embraces the idea of balanced approach that considers ecotourism both from eco-centric and anthropocentric planning ethics, and addresses the issues of development without destroying the environmental resources. Based on this concept, several principles have been portrayed for ecotourism development, whose key purpose is to benefit local people, conserve resources and satisfy tourist's need by adopting appropriate policies, guidelines, and responsible behavior by the tourists, host community, and the tourism industry.

The Quebec Declaration also stresses on the participation of indigenous communities in the planning, development and operation of ecotourism to actively contribute to well- being of communities and the conservation of resources, as well as interpretation of local heritages to the tourists who often visits in small size groups. These criteria or principles seem more like ethics or norms of ecotourism, and demand for the consideration of balanced planning approach i.e. combination of anthropocentric as well as eco-centric standpoint. In addition, these criteria emphasize on the concept of sustainable development and sustainability (e.g. CeballosLascurain, 1996; Honey, 1999; Fennell \& Eagles, 1990; Lindberg \& Hawkins, 1993; Tourism Concern \& WWF, 1991; Wight, 1994; Ziffer, 1989).

\section{Ecotourism Impacts in the Protected Areas}

Ecotourism is an instigator of change (Wall, 1996). These changes reveal the impacts of ecotourism which are often measured in terms of positive (beneficial) and negative (detrimental) impacts. The impacts result from the complex interrelationship among host communities, tourists, and natural environments, and are mutually interdependent (Mathieson \& Wall, 1982). Several scholars have conducted studies on the potential impacts of (eco)tourism on the destination communities and environment, which are presented into three dimensions: economic; environmental; and socio-cultural (e.g. Boo, 1993; Nyaupane \& Thapa, 2004; Stone \& Wall, 2003; Weaver, 1998; Pizam \& Milman, 1984; UNESCAP, 1999; Gunn, 2002). The impacts vary widely with variation in the quality of attraction, accessibility, regulations, management, and many other factors. Extensive research has justified that benefits of ecotourism can be fully realized (Eagles et al, 2001; Hatton, 1999; Mitchell \& Reid, 2001; Norris, 1992; Slinger, 2000); however in some cases ecotourism has fallen short of its objectives that have been set for it (Nepal, 2000; Ross \& Wall, 1999; Place 1991; Walpole \& Goodwin, 2000).

Socio-cultural Impacts: Extensive research has confirmed that tourism not only plays an important role in the economic development, but also brings enormous socio-cultural impacts 
(Hall \& Lew, 1998; Lindberg et.al, 2001; Pizam \& Milman, 1984; Smith 1989). According to Pizam and Milman (1984), socio-cultural impacts are the "ways in which tourism is contributing to changes in value systems, individual behavior, family relationships, collective lifestyles, moral conduct, creative expressions, traditional ceremonies and organizations". It shows that the changes in communities might be the structural such as change in livelihoods and increase in population or changes in intangible heritages. Similar definitions have been proposed by many other scholars (e.g. Fox, 1977; Honey, 1999; TIES, 2002).

The socio-cultural changes or impacts in local communities are brought by the interaction between host and guest, and the difference in their basic values and logic systems; religious beliefs; traditions; customs; lifestyle; behavioral patterns; dress codes; sense of time budgeting as well as attitudes towards strangers (Inskeep, 1991). In addition to type of tourist's activities, the time of interaction between tourists and local communities also determine the magnitude of socio-cultural impacts. Scholars such as, Cater (1987), Butler (1990) and Wearing (2001) strongly argued that longer the duration of tourist's stay in the destination, more will be the tourists' understanding of host community, and also accelerate the changes on the socio-cultural pattern of the host. It shows that the host-guest interaction either leads to an improved reputation and visibility of the host community among the eco-tourists or it can also be overly intrusive and harmful despite the best of intentions among tourists (Wearing, 2001).

The increase in number of tourists and their interaction with host communities can bring several local benefits, such as: new services and facilities become accessible to the host populations which are actually developed to cater growing number of tourists; local arts, traditions and cultural activities are revived and preserved as a tourism product; and attitude of local people and tourists towards each other may be enhanced (Diamantis, 2004). Moreover, tourism has also provided new jobs to women and youths that led to their economic independence and integration into society. Alternatively, in some cases, cultural attractions through commoditization become overtly commercialized in nature, satisfying the visitors need but losing all meaning and significance for the local communities (Wearing, 2001). Moreover, in contrast to cultural revival, scholars also reported the "demonstration effect" where local people imitate tourists" behavior and their way of life to become more westernized like tourists (de Kadt, 1979; Mathieson \& Wall, 1982).This impact is supposedly caused in large by perceived power differentials between tourists and community members (deKadt,1979). Moreover, the cultural concerns in the interaction between tourists and communities can also be viewed in terms of assimilation, acculturation and cultural drift (Wall \& Mathieson, 2006).

In many cases, tourism has created social problems on the communities. For example, in Costa Rica, Campbell (1999) reported the negative impacts of tourism such as: increased drug use, disorder, prostitution, crime, foreign land ownership and over-development. Influxes of tourists and outsiders such as entrepreneurs and labors also exacerbate the overcrowding which may displace local people to the periphery from the center of tourism activities, and may also create conflicts between locals and outsiders specifically for grabbing tourism opportunities. It may also contribute to power differentials between tourists and local people that further led to separation and antagonistic relation between them. Physical displacement may also reduce the local access to the PA resources also reduces local benefits from ecotourism. 
These socio-cultural impacts of ecotourism on the host communities can be evaluated through proper judgment on changes on the population structure; transformation of types of occupation; transformation of values; influence on traditional way of life; and modification on consumption pattern of local people (Wearing, 2001). It is, however, crucial to note that the identification and examination of impacts depends on value judgments (Eagles, 2001), and who makes the judgment is a critical element of decision making process. In this regard, appreciation of local communities and their customs and traditions as a process of mutual respect and understanding between different societies is crucial to promote long term sustainability.

Certainly, there exist mixed views about impacts of ecotourism on the local communities. In some cases, scholars pointed that ecotourism development has faced organized protests of communities to ensure that the projects should not be implemented in their areas. While on the other hand, increasing dependency of communities on ecotourism to receive economic revenues and benefits also make them unable to oppose ecotourism development. In this regard, the issues of who gets benefits, and to what extent, are a crucial concern specifically to sustain ecotourism development at the destinations. The widespread conception is that once communities get more benefits, they will continue to support the tourism development. The perceptions and responses of local communities towards ecotourism development are thus crucial to produce better results as well as sustain ecotourism for long-term.

\section{Community perceptions towards impacts of ecotourism}

Telfer and Sharpley (2008, p.118) argued that interaction between tourists and communities may occur in the "front stage" where more formal service, performance or demonstration is given, or in the "backstage" where tourist view into the real life of residents, which may or may not be like the formal performances. The perceptions and attitudes of local people towards tourism thus depend, to a large degree, on the interaction with tourists and the possible consequences of tourism. Murphy (1985, p.120) pointed that attitudes are personal and complex; however, in terms of community attitudes, there are three main determinants. First is the type of contact which exists between resident and visitor. Second is the relative importance of the industry to the individual and community, and the third is a tolerance threshold.

A number of models have been used to elucidate the response of communities towards tourism. One of the first models is the "Irritation Index" proposed by Doxey (1976), who consider community attitudes towards tourism go through a series of stages such as euphoria, apathy, irritation, antagonism and the final stage when a community is undermined and destination lose its attraction (Telfer \& Sharpley,2008). It indicates that local perceptions of tourism impacts are linked with the stages of development, for example: positive attitudes are found at less developed destinations or at initial stage of tourism, however with increase in tourism they may perceive negative impacts and oppose the tourism development. The Doxey's model however has been criticized for two reasons. First, the attitudes of communities towards tourism may not always move in one direction such as from positive at the start to the negative at later stages; opposite may also be true. Second, it may be misleading for communities to have dominant attitudes (Wall \& Mathieson, 2006). 
In a cross-cultural study of European tourists holidaying in Turkey, Dogan (1989) evaluated the response of local communities towards tourism from resistance to adoption of western culture, and proposed four categories of local responses, for example: resistance, retreatism, boundary maintenance, and adoption. Although several models have been used to examine community perceptions and responses; the theoretical foundation for these studies is largely the social exchange theory, which was proposed by Ap (1992) to explain local attitudes towards tourism development. This theory contends that attitudes are influenced by the perceptions of benefits (positive impacts) associated with tourism development. It revealed that local people evaluate tourism in terms of expected benefits and costs obtained in return for their services that is social exchange (Lee \& Back, 2006). Therefore, residents who perceive themselves as benefiting from tourism will most likely to view it positively; while those who perceive themselves as incurring costs will be negative towards tourism (Telfer \& Sharpley,2008). Nevertheless, since Ap's (1992) study, social exchange theory has been widely used in evaluating local attitudes and perceptions towards tourism.

This theory is most frequently confirmed by studies that link positive attitudes towards tourism development with economic benefits (Lee \& Back, 2006; Walpole \& Goodwin, 2001). However, understanding of local attitudes is not as simple as weighting up the perceived benefits and costs. In addition to the stage of tourism development, local attitudes and perceptions are also influenced by several other factors, for example demographic variables influence attitudes indirectly through values (Lindberg \& Johnson, 1997). Attitudes are also related with individual's characteristics such as level of contact with tourists, length of residence at destination, ethnicity (Liu \& Var, 1986), economic dependency (Milman \& Pizam, 1988), education and many others. As such, there would be no universal indicators to evaluate community perceptions and attitudes towards (eco) tourism, rather, site-specific criteria and assessment is crucial. Once the perceived benefits of ecotourism outweigh the costs, local people may continue to support ecotourism development.

\section{Research Methodology:}

This study is primarily associated with the interpretivist paradigm and employs a qualitative approach with descriptive and explanatory methods. The Settlements around Annapurna Sanctuary Trail (AST) such as Dhampus, Landruk, Ghandruk and Birethanti are selected for detailed investigation. Multiple methods of data collection such as questionnaire survey with households $(n=199)$, semi-structured interview with key informants $(n=8)$, participant observation, informal discussion and documentation analysis have been used. The set of questionnaires were designed with open and close ended questions that provided respondents an opportunity to express their opinions and suggestions. A 5-point Likert scale ranging from strongly agree (1) to strongly disagree (5) has been used in evaluating perceived impacts of ecotourism. Besides impacts, the scale varies according to set of questions and its objectives. Documentation consisted of collection of written documents from the official records, relevant publications, reports, photographs and videos. Extensive discussion and field notes were carried out through in-depth interviews, participant observation, and informal discussion. Use of variety of research instruments and data sources enhanced triangulation approach that provided crossdata validity checks and the reliability of data sources. 
Preliminary discussion with the key informants at local level such as the local leaders, and entrepreneurs was conducted to identify the number and type of enterprises, number of households and their occupation, concentration of the tourism related enterprises and services, location and condition of local heritage, and associated issues. After the preliminary discussion, an extensive tour of the settlement was conducted with the help of experienced local residents which helped to define the boundary of study areas. During the selection of survey unit, stratification criteria such as location of households, type of enterprise, use of the building and the household activities were used. Considering the spatial context, households were selected from the Major Trail (MT) i.e. major streets in the settlements as well as from off-the trail (OT) i.e. secondary or branch streets in the settlements. These were selected as survey units through systematic and stratified random sampling. The approximate distance of a peripheral household from main trail is supposed to be 500 meters (maximum).

Figure 1: Map showing typical settlements in the Study Area (not in scale)

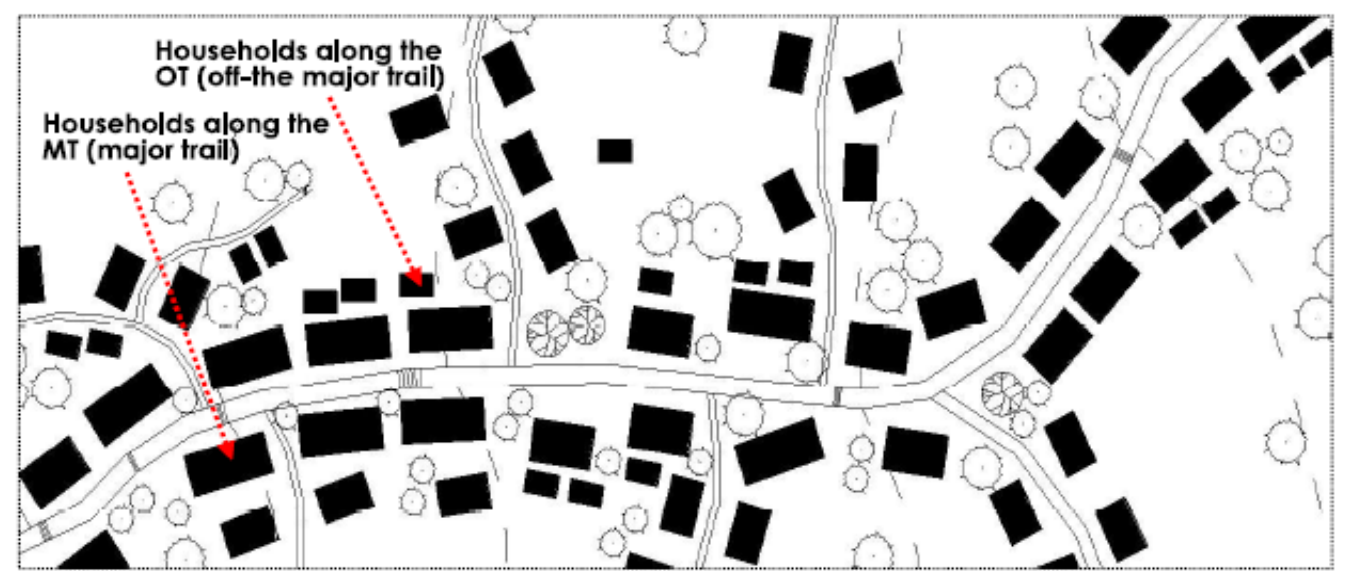

(Source: Author)

Households representing both the locations were selected specially to understand the perceptions and attitudes of households towards ecotourism development and its socio-cultural impacts. It helped to compare the perceived tourism impacts among the households in both the locations (MT and OT). In addition to spatial location, the type of use of the building and the engagement of households in specific activities were the additional criteria for selecting the households as a survey unit. Attempt was made to seek maximum responses from different people engaged in different types of activities.

The examination of perceived impacts would help to understand the current stage of ecotourism development as well as the efficacy of existing ecotourism policies and plans, which is crucial to determine the direction of ecotourism development and state of sustainability. It also helps to predict future patterns and impacts of ecotourism development. The key criteria or issues that will be examined as perceived socio-cultural impacts in the study areas include (i) Local values, customs and identity (i.e. change in traditional values and customs; and change in family relationship and cohesiveness) (ii) Local art, craft, and heritage conservation (i.e. appreciation and revival of traditional art and crafts; conservation of local architecture, heritage and overall built environment; and codes of conduct) (iii) Cultural exchange and appreciation (i.e. interaction, intercultural appreciation and harmony between tourists and local community; education, and interpretation facilities) (iv) Crime and vandalism (i.e. use of drug, sexual 
harassment, vandalism and other crimes) and (v) Quality of life (i.e. social services and facilities; local participation in planning and decision making; and overall satisfaction and happiness).

\section{Overview of the Study Area:}

Established in 1986, the Annapurna Conservation Area Project (ACAP) covers a land area of 7,629 Sq. Km., the largest conservation area in Nepal. The ACA is a land of spectacular beauty and diversity, stretching from the subtropical zone in the south to the alpine and dry alpine steppes in the north with altitudinal variation from $100 \mathrm{~m}$. to the $8091 \mathrm{~m}$. It is unique and crucial for its outstanding landscape, diverse flora and fauna, and the most geographically and culturally diverse area in the world (Nepal, 2000). It is a region of deep river valleys, gorges, and high mountain ranges including two of the world's tallest mountains Dhaulagiri $(8167 \mathrm{~m})$ and the Annapurna $(8091 \mathrm{~m})$. The drainage system includes several rivers as well as high altitude glaciers and lakes (Nepal, 2003). Its diversity in terms of topography and climatic condition is favourable to produce variety of vegetation (1236 plants), mammal (102), reptiles (40), birds (488), amphibian species (23), fishes (20) and many wild endangered animals such as Himalayan Thar, barking deer, blue sheep, red panda, snow leopard and langur (NTNC, 2009). The majority of the residents live at subsistence level or below with a high level of dependence on natural resources.

Annapurna Sanctuary Trail (AST) is one of the oldest and popular tourism trails in the region starting from Dhampus and Birethanti leading to the base camp of Mount Annapurna (4070m) and Mount Machhapuchre (Fishtail) (3703m). It passes through several ethnic villages in the southern Annapurna region, of which Dhampus, Landruk, Ghandruk and Birethanti have specific importance attracting thousands of tourists every year. These villages are the major stop-points for trekkers going to or returning back from the base camps and thus have been influenced by the tourism activities. Ghandruk, predominantly a Gurung ethnic village, is the region where the pilot project of ACAP was first implemented in 1986 to mitigate the environmental problems of the region. The unique geographical, biological and cultural diversity has made the area the most popular trekking destination in Nepal (Nyaupane \& Thapa, 2004). The AST follows the southern slopes of Annapurna range and offers dramatic views of some of the highest and most beautiful mountains in the world. It also exhibits the diverse and fascinating ethnic culture of the Gurungs, Magars, Bahun, Chhetri and Kami. The livelihood of these communities has been largely influenced by the tourism development in the region.

The village of Dhampus lies within the jurisdiction of then the Dhampus Village Development Committee, whereas the village of Landruk belongs to then the Lumle Village Development Committee, and that of Ghandruk and Birethanti belongs to then the Ghandruk Village Development Committee. While the Village Development Committee (VDC) in the rural context was subdivided into nine wards, these settlements only form the portion of the VDC and cover only some of its wards which lie along the major tail of the Annapurna Sanctuary. The total households and the population of the three VDCs mentioned above reached to 2778 and 11060 respectively (CBS, 2012). Now these VDCs have been restructured as Rural Municipalities.

Since the inception of ACAP, the plans and policies advocate the concept of ecotourism (sustainable tourism) as a tool to promote conservation of local heritage (natural and cultural) vis-a-vis socio-economic development of the communities. Ecotourism has become one of the major alternatives for supporting livelihoods of local people in the ACA. The region is attracting 
different types of tourists including luxurious, pleasure seeking, adventurous, holiday making and economical budget backpackers. It has been visited by large number of international tourists every year which usually accounts more than 60 percent of the country's total trekkers (NTNC, 2009). Since the opening of the first lodge in Ghandruk village in 1976, there has been a significant growth in the construction of lodges, and tourism services in the region. By the end of the year 1999, there were 518 lodges in the region, which increased rapidly and now reached over 1,000 lodges, and tea-shops along with hundreds of other subsidiary services especially to cater the trekkers and pilgrims (NTNC, 2009). In the AST, there are also more than 300 lodges and tea-shops operated and registered under the Annapurna Sanctuary Tourism Entrepreneurs Committee. The number of international tourists visiting the region has increased from 14,332 in 1980 to 47584 in 1995 and 99296 in 2011 (NTNC, 2009; MoCTCA, 2012). A steady growth in international tourist's arrival was observed till 2000 when it reached to 73,407 . Since then it was however dramatically dropped due to various reasons including national and international security concerns, and reached to 38,642 in 2002 Since the restoration of peace in 2006/2007, international tourist arrival was increased and reached to 99296 in 2011(NTNC, 2009; MoCTCA, 2012). Tourism has thus become one of the prime economic activities in the region, providing local employment to over 50,000 people during the peak season (Nepal, 2003).

Figure 2: Map of ACA showing locations of tourist villages along the AST and other trails

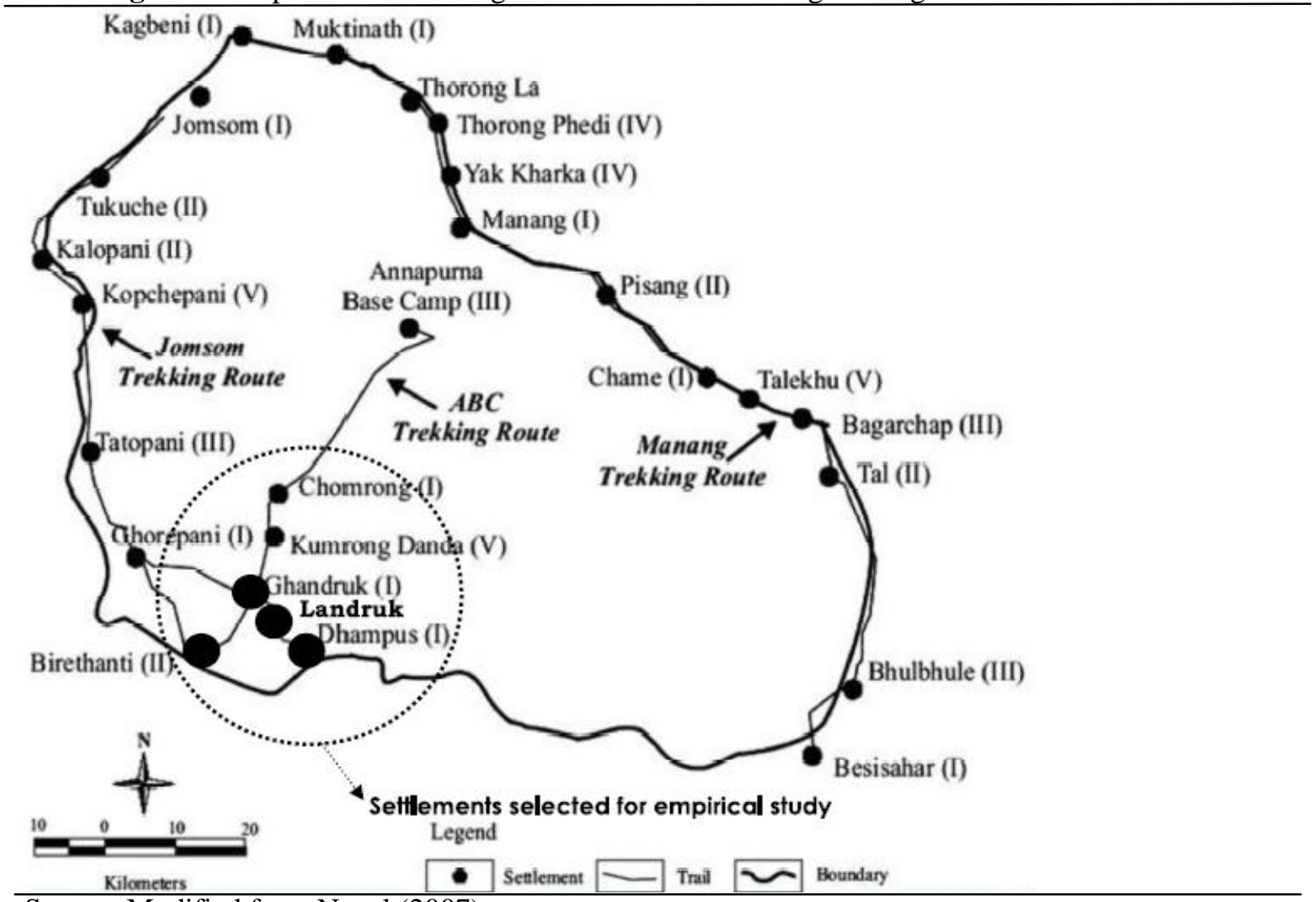

Source: Modified from Nepal (2007). 


\section{Perceived Socio-Cultural Impacts of Ecotourism: Research Findings and Discussion}

One of the significant concerns arising from the rapid development of tourism in the developing destinations is its socio-cultural consequences on the lives of indigenous people (Pizam \& Milman, 1984; Hall \& Lew, 1998; Lindberg et.al., 2001). Assumed to be a benign idea, ecotourism maximize social benefits while minimizing socio-cultural costs. In this regard, the socio-cultural impacts of ecotourism will be discussed critically specifically with reference to the findings of the perceptions and attitudes of local communities in the AST including MT and OT.

\section{Community perceptions towards significance of local culture and heritage}

Akin to natural environment and scenery, indigenous culture, traditions, and archaeological heritage play significant role in the development of ecotourism. In case of AST, majority of residents believed that local culture, tradition and heritage play vital role to promote sustainable tourism development. The survey results (chart 1) also reports that $91 \%$ respondents in AST strongly acknowledged their culture and heritage significant in attracting tourists in their villages. Almost similar proportion of respondents in MT (91.7\%) and OT (90.1\%) also considered their culture and tradition crucial in promoting tourism development. Comparatively, respondents in OT seem more conscious to their culture and thus value more to it than that of MT. In addition to local culture, residents also perceived built heritage and historical (archaeological) sites as the crucial elements for (eco) tourism development in the region.

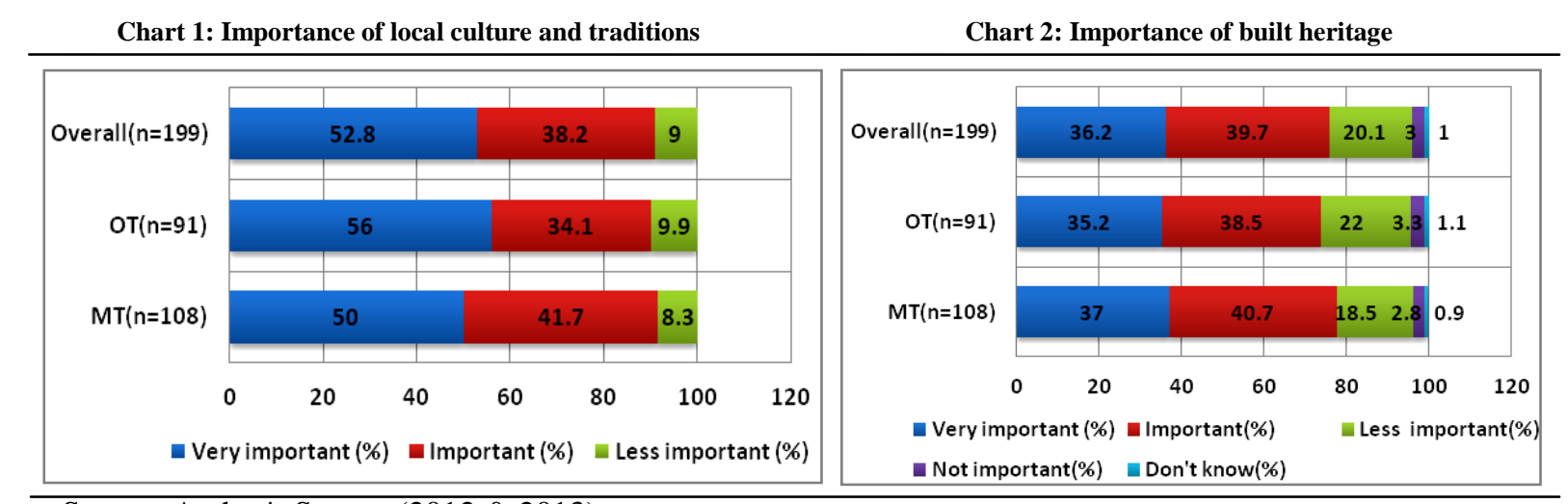

Source: Author's Survey (2012 \& 2013)

The survey results (chart 2) reveal that majority of respondents (75.9\%) perceived their architectural heritage as significant for attracting tourists. It is crucial to note that majority of residents seem positive towards indigenous culture and their heritage, while the influence of tourist culture is also growing in the region. With regard to MT and OT, relatively more residents in MT seem positive with the built heritage than that of OT. Nevertheless, both local culture and architectural heritage are assumed important elements in ecotourism development which the local residents also valued as important assets for sustainable community development.

\section{Community perceptions towards tourism-induced socio-cultural changes in their life}

The survey results reveal that majority of respondent in AST perceived ecotourism as an agent of socio-cultural changes. The Chart 3 shows most of the respondents (83\%) admitted that tourism 
has changed their socio-cultural life to some extent; however, only $15.6 \%$ disagreed with the statement. Respondents in MT and OT perceived these changes differently such as $17.6 \%$ in MT agreed with the facts that tourism has brought significant socio-cultural changes in their life than that of $5.5 \%$ in the OT; whereas almost equal proportion in both areas (MT: $70.4 \%$, and OT: $71.4 \%$ ) believed that these are only minor changes. On the other hand, $22 \%$ in OT and $10.2 \%$ in MT did not perceive socio-cultural changes at all. Nevertheless, it is true that rapid growth of tourism has changed the lives of residents both in the MT and OT though in a varying degree. To explore the nature of these changes, households were further asked how they view tourisminduced socio-cultural changes (see chart 4). Interestingly, of the total respondents $(n=166)$, majority $(96 \%)$ perceived these changes positively and rests $(3.6 \%)$ shared mixed views both 'good' and 'bad'. Nearly similar proportion of respondents in MT (95.8\%) and OT (97.1\%) perceived these changes positively. The positive changes are reported as increase in social services and facilities, intercultural appreciation, and understanding of foreign culture. On the other hand, negative changes include loss of traditional socio-cultural activities, community cohesiveness, and gatherings.

Chart 3: Has tourism changed your/household life?

Chart 4 : How do you view these changes?

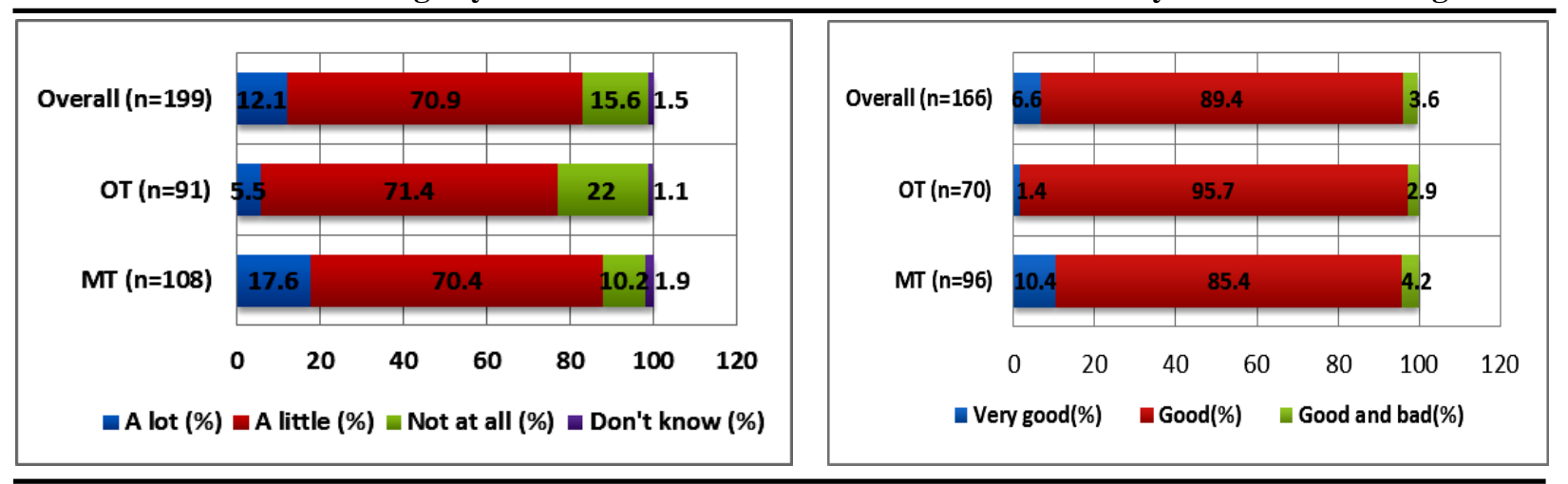

Source: Author's survey (2012 \& 2013)

Similar to the changes in the socio-cultural life of individual households, most respondents (97.5\%) believed that tourism has changed their community as well (see chart 5), where $13.1 \%$ rated these changes as major ('a lot'), and $84.4 \%$ as minor ('a little'). Slightly larger proportion of respondents in MT (15.7\%) perceived these changes as major as that of OT (9.9\%). Conversely, respondents perceiving changes as minor are slightly more in OT (86.8\%) than MT $(82.4 \%)$. Those who perceived socio-cultural changes in their community $(n=195)$ were further asked how they viewed such changes (see chart 6). Overall, 69.1\% perceived the impacts positively; 29.4\% had mixed views (both good \& bad); and rests (1.5\%) perceived negatively. Respondents in MT (75.5\%) seemed more likely positive with the changes than that of OT $(61.4 \%)$. Furthermore, respondents perceiving changes both 'good and bad' are relatively higher in OT $(35.2 \%)$ than MT $(24.5 \%)$. Thus, tourism has indeed brought socio-cultural changes in the communities which are perceived more positively by the residents in MT than OT. It is apparently because residents in MT are mostly the tourism entrepreneurs who usually involve in 
tourism activities, receive more benefits from it, and expect growth of tourism in the region, thus perceived the tourism-induced community changes more positively than farmers or nonentrepreneurs along OT, who do not often involve in tourism and receive fewer benefits.

Chart 5: Has tourism changed your community?

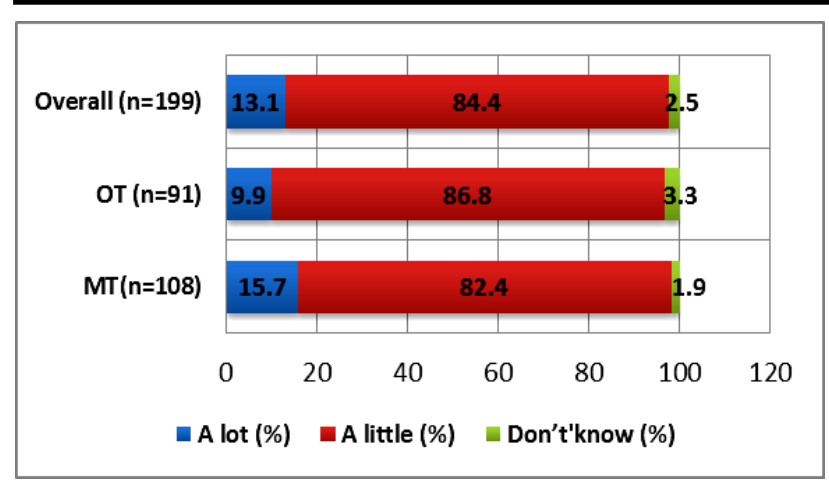

Chart 6: How do you view these changes?

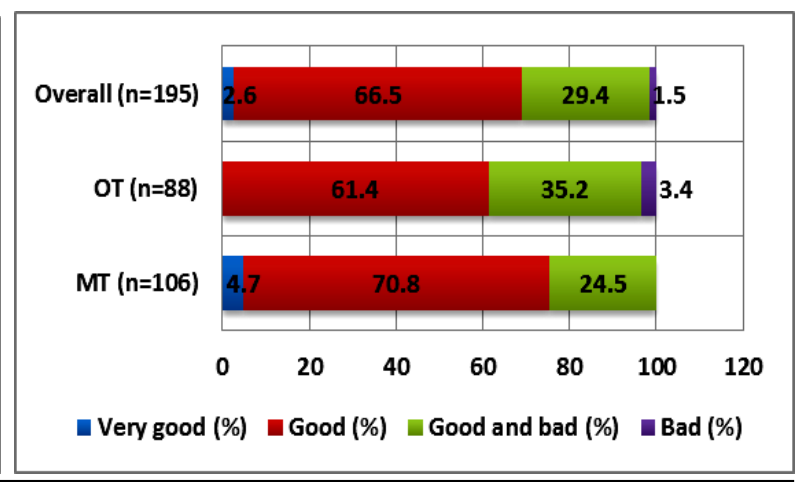

Source: Authors Survey (2012)

\section{Revival of local culture, traditions and heritage}

Well-planned ecotourism development contributes to the preservation and revival of local culture, traditions and built heritage particularly through education, awareness, and financial contribution. In case of AST, survey findings reveal mixed perceptions of local residents towards tourism's role in the preservation of cultural heritage. Majority of respondents $(98.5 \%)$ believed that tourism has enhanced resident's feeling of pride and respect towards their indigenous culture, and traditions. However, with regard to revival of cultural heritage, they perceived both positively as well as negatively. About $28.6 \%$ respondents believed that indigenous arts, crafts, customs and heritage have been revived; however majority (40.7\%) disagreed with this statement, and rests (30.7\%) neither agreed nor disagreed.

Residents in MT and OT perceived socio-cultural impacts differently. For example, 41.7\% respondents in MT agreed with the revival of local culture and heritage through tourism development, however it is only $13.2 \%$ in OT. Conversely, while nearly half of respondents $(49.5 \%)$ in OT disagreed with this statement; only $33.2 \%$ in MT did so. Differences in resident's perceptions could be because of the different degree of resident's involvement and relationship with tourism. Specifically, potential economic benefit from tourism is considered as one of key factors determining community perceptions toward tourism development. More the direct benefits from tourism, more residents will perceive it positively and vice-versa. As residents in MT are more likely to receive direct economic benefits from tourism than that of OT, they perceived tourism development more positively than that of residents in OT, who are usually the farmers or non-entrepreneurs, and do not directly involve or less involved in tourism.

One of the significant features of indigenous culture in the AST is the traditional dances, songs and dresses. In each village, women's group has operated cultural shows to the tourists where indigenous cultural activities such as Gurung folk dances and songs are performed by the local artists. Based on the demand, each dancing group performs the shows in different hotels and lodges in the village, and collects funds for community development and awareness activities. 
On one hand these cultural programs have been supporting continuity of cultural practices of Gurung community to some extent; while on the other hand, some residents commented that the group members nowadays do not wear their traditional dresses nor sing folk songs. On the contrary, residents criticized that artists tend to sing modern radio songs and wear jeans and nonlocal dresses during the cultural shows, which does not convey cultural richness of Gurungs to the tourists. More specifically, these activities do not actually provide sense of cultural authenticity of Gurung ethnicity.

Wearing (2001) pointed that cultural attractions through commoditization may become overtly commercialized in nature that satisfy the tourists need but may lose its authenticity and significance for local communities. Research findings also justify that there has been a commercialization of local culture, and heritage in the AST. Over half of the respondents (51.2\%) agreed with this statement, while only $9.5 \%$ disagreed and rests $(39.3 \%)$ were unsure. Findings reveal significant differences in the perceptions of residents along MT and OT. About $38.9 \%$ respondents in MT $(38.9 \%)$ perceived that local culture has been commercialized; which is nearly two third in OT (65.9\%). It indicates that residents in OT (mainly the farmers) are more sensitive to the cultural changes than that of MT (mainly the entrepreneurs). The reasons for different perceptions may be because of the different level of tourism development, interaction and local participation. Butler's life cycle (1980) also argued that, with increase in tourism, the authenticity of local culture and heritage might be lost if proper intervention are not taken on early stage of planning. In the AST, local youths have been attracted towards tourist culture and imitate tourist behavior, dress and fashion. Moreover, some of the youths have also adopted alcohol and drugs. In this regard, one of the elderly residents in AST responded that:

"Our new generation is more inclined towards tourist culture and is forgetting our indigenous
traditions, festivals, and culture. They often imitate tourist behavior, food, fashion and culture and
value more to the tourist culture thinking that westerners are more civilized and what they do is the
right. On the other hand, as most of the festivals of Gurungs fall during tourist seasons; local people,
mostly the tourism entrepreneurs, do not have time to celebrate our festivals and cultural activities.
Thus, Gurung culture of this region is losing its authenticity with the growing influence of tourist
culture on community"

This argument is further validated from the findings of the household's survey. More than half of the respondents $(61.9 \%)$ agreed that locals are now inclined towards tourist culture. Reasonably, respondents in OT (75.8\%) are more likely to agree with the statement than that of MT (50\%). Scholars such as de Kadt (1979), and Mathieson and Wall (1982) pointed that copying of tourist behavior and their way of life to become more westernized like tourists by the indigenous community is a demonstration effect of tourism, which is also gradually increasing in the AST. In addition, although these changes in socio-cultural values would have been partly caused by the factors such as radio, televisions, newspaper, and migratory pattern of locals to the cities and abroad; rapid development of tourism in the AST is the fundamental reason accelerating the changes among the local communities.

Undoubtedly, tourism has brought significant changes in local culture and community life style. Local residents are now increasingly motivated towards financial benefits from tourism, with less attention towards family cohesiveness and kinship among the locals. Significant number of respondents $(15.1 \%$ ) agreed that tourism has increased negative changes in the family 
relationship and cohesiveness, whereas nearly half of the respondents $(48.7 \%)$ were unsure (neutral), and rests (36.2\%) disagreed. It is found that slightly larger proportion of respondents in MT agreed (16.7\%) with this statement than that of OT (13.2\%). However, significant proportion also disagreed in both MT (37\%) and OT (35.2\%). Similarly, another substantial change in the AST is the transformation of built space and physical environment. The rapid development of tourism has also transformed the shape, size, and functional characteristics of rural settlements along with tremendous changes in the architecture (Nepal, 2003; Chan \& Bhatta, 2013). The design and construction of hotels and lodges along the trail has not addressed the features of local architecture and identity of the region. These buildings neither have adopted local technology, materials, and architectural style nor considered socio-cultural essence of the Gurung village. Only few lodges have been constructed in traditional architectural style, one of them is the Gurung Cottage; a popular tourist lodge in the Ghandruk Village. During an interview, the owner of the lodge who is also a chairman of Annapurna Sanctuary Tourism Entrepreneurs Committee commented that:

"It's really a big problem that tourism entrepreneurs have not well-recognized the significance of our cultural heritage, identity and architecture. Most of them think that tourists only want modern facilities and services like western countries, which is, in fact, not entirely true. According to my experience of more than a decade, majority of tourists prefer to enjoy local food, customs, culture and architecture. However, we, specifically lodge owners/hoteliers, have not been able to supply our original local products. We have not only copied the foreign food items but also introduced so called modern architecture which seems so ugly and alien to this region. I am happy that tourists prefer Gurung Cottage because of its vernacular taste in architecture and services. Tourists are fully satisfied and happy with my lodge. But, it's really sad to say that staffs and members of many of the community organizations working for conservation and development have also constructed their hotels, lodges and houses in modern style concrete structure without incorporating local architecture and materials. I think lack of knowledge and awareness about the significance of vernacular architecture and its connection with tourism are the key reasons undermining the local architecture and heritage in the AST".

During discussion, some hoteliers however also replied that newly constructed buildings have more space and rooms essential for catering growing numbers of tourists. They stressed that the buildings are constructed with reinforced cement concrete (RCC) technology which is more durable, and consume less amount of timber as compared to the traditional houses. On the contrary, key informants stressed that as new buildings seem ugly and alien to indigenous culture; there could be other possibilities to incorporate local architectural features even in the RCC buildings, so they should have adopted vernacular style rather than introducing alien features. Lack of proper regulations and architectural control on the private land and the lack of awareness among residents are the key reasons accelerating the construction of hotels in alien architectural style.

From the discussion, it is arguably concluded that local architecture, built heritage, and traditional identity of Gurung ethnicity have been threatened by the rapid and unplanned growth of tourism. The increased tendency of local people, specifically the youths and tourism entrepreneurs, to abandon their traditional customs, values and heritage and their increased desire to copy tourist attire, behavior and culture is similar to the Dearden's (1991) arguments in the study of trekking tourism in Hill-Tribes of Northern Thailand, where tribal people exposed to trekkers were transformed from tribal host with traditional hospitality to small 
tourism entrepreneur with cash transaction, and finally the tourism entrepreneur with commercialization of local culture. It is also important to note that not all the activities of tourists bring negative impacts on the local customs and culture. Some residents still continue to practice local culture, social values and practice and also receive tourist dollars. In the policy level, though ACAP has stressed on the conservation and revival of local traditions and built heritage (NTNC, 2009); in practice, it has been given least priority. Additionally, most of the tourism entrepreneurs including both locals and outsiders have placed more emphasis to the convenience of tourists, with less or no priority for local architecture, culture and heritage conservation.

\section{Fostering interaction and inter-cultural appreciation}

Ecotourism is assumed as a tool to enhance host-guest interaction and inter-cultural appreciation (Ross \& Wall, 1999). Unlike the cultural degradation caused by the mass tourism, ecotourism is considered supportive to enhance the understanding of indigenous culture, knowledge, skills, traditions, and heritage. Interaction among hosts (residents) and tourists is thus inevitable to promote cultural continuity and identity. Majority of the respondents in AST (65.3\%) agreed that interaction between tourists and local community has increased cultural exchange and respect to each other, whereas 5\% disagreed, and rests (29.7\%) were unsure. Significant difference has been identified in the perceptions of residents along MT and OT, such as, $78.7 \%$ respondents in MT agreed with the statement, whereas it is only $49.5 \%$ in OT. It could be because the residents along MT have more regular interaction with tourists than that of residents in OT. Butler (1990) and Wearing (2001) also pointed that more the duration of interaction between host and guest more will be the understanding of local culture and thus will respect each other and appreciate socio-cultural values.

Eco-tourists are usually assumed purposeful and responsible and expected to appreciate local culture and heritage. In case of AST, majority of respondents (81.9\%) agreed that tourist's stay in their villages has increased the appreciation of local culture and heritage. Reasonably, higher proportion of respondents in MT $(87.0 \%)$ has perceived tourism positively in appreciating Gurung ethnic culture than that of OT (74.7\%). The difference in the residents' perceptions could be because of resident's level of interaction, involvement and dependence on tourism. With regard to overall satisfaction of local people towards tourists' behavior, findings reveal that over half of respondents $(50.7 \%)$ are satisfied with tourist's behavior, whereas $2 \%$ disagreed and rests $(47.2 \%)$ have neutral response. Respondents in MT (58.3\%) seem more likely positive with the tourist behavior than that of OT $(41.8 \%)$. It indicates that residents in both areas did not perceive tourist's behavior so negatively; only some key informants are more conscious about potential negative impacts of tourism on the indigenous culture. It's ironic that while tourists respect local culture and traditions; increasing number of local residents, specifically the youth, are neglecting their own culture and attracting towards tourist culture. It is thus indispensable to educate, aware, and encourage local youths to respect, preserve and continue their local culture and tradition.

\section{Enhancing education and awareness}

Education, awareness, and proper interpretation of indigenous cultural resources to the tourists are crucial to motivate both locals and tourists for responsible and ethical behavior towards communities and their culture. As Ross and Wall (1999) asserted that education and awareness 
activities are the backbone of ecotourism development that will enhance mutual understanding between tourists and locals, and thereby increase respect towards indigenous culture, traditions and heritage. During the interaction, indigenous communities should be able to properly communicate and interpret their local lifestyle, and cultural authenticity to the tourists. In the AST, residents, specifically the farmers and non-entrepreneurs, can hardly communicate in English language with the tourists, however tourism entrepreneurs and trek guides could do. Nevertheless, significant proportions of residents, including those who have no formal education, have now become able to communicate and behave with tourists appropriately.

Survey results reveal that $29.6 \%$ respondents in AST agreed with the statement "local people can easily interpret their culture and social activities to the tourists", whereas $36.1 \%$ disagreed, and remaining (33.7\%) neither agreed nor disagreed. Comparatively higher respondents from MT (36.1\%) agreed with the statement than that of OT (22\%). It is because tourism entrepreneurs mostly live along the MT, and they more often interact with tourists than residents in OT. Tourism has also provided learning opportunities to the residents to explore foreign culture that has opened their eyes towards rest of the world. Most of residents believed that they have learnt many good things from the tourists such as cleanness, mutual respect, and importance of their local culture, and traditions. One of the respondents (entrepreneurs) commented that:

"We have got opportunities to communicate and enjoy dinner with some of the most educated people in the world such as professors, scientists, doctors, engineers, and many others. We have also learnt so many new things from tour operators, trek guides and porters. We all sit together and share our experiences. There is no any cultural discrimination between tourists and locals. We have still many more good things to learn from them. This is possible only because of tourism development in the region".

Undoubtedly, tourism has benefited local residents either directly or indirectly. However, residents in OT criticized that educational and economic benefits are mostly accrued to the hoteliers and residents along MT, with less or no benefits to peripheral areas. The proximity of residents along the major trail (MT) and their frequent interaction and involvement in tourism activities has benefited them more than that of OT. Community perception usually changes with changes in the tourism intensity, its impacts on local people and temporal dimension. One of the first hoteliers in the Ghandruk commented that "in the early days, none of the local people wanted to invite tourists and serve them at their home; however nowadays everyone want to have at least a group of trekkers in their lodge and hotels". It indicates the transformation of local communities from restraint nature to supporter (entrepreneurs) of tourism.

Some residents in AST, with support of ACAP, have operated cultural museum, such as the privately-owned 'Gurung Museum' in Ghandruk village, which displays artifacts about local culture, customs and daily life style of Gurung people that inform tourists about indigenous community lifestyle. It has become one the key tourist attractions in the region, and provided financial benefits to the owner through collection of entrance fee and selling of local arts and crafts. Information on the local key attractions and trekking trails has also been provided in each tourist spots either by the local hotels or the ACAP. About $45.2 \%$ respondents perceived that the educational facilities such as museum, maps and information are well established in the AST, whereas $26.1 \%$ disagreed and rests $(28.6 \%)$ unsure. While over half of the respondents in MT (53.7\%) agreed with this statement; only $35.2 \%$ in OT did so. And nearly one fourth of 
respondents in both areas disagreed with the statement (MT: 26.8\% \& OT: 25.3\%). On the whole, socio-cultural awareness and educational benefits are, to some extent, received by the tourists and some local residents mainly in the MT; it is indispensable to implement more effective educational programs on local culture, heritage and socio-cultural life style that would aware and motivate local residents, both in MT and OT, and the tourists towards conservation of local culture.

\section{Improving overall quality of life}

Compared with situation before 1986, residents along the AST perceived that tourism has now significantly improved the social facilities and overall quality of their life. Since the inception of ACAP, emphasis was provided on the development of community infrastructure and well-being as a strategy to motivate local residents towards protection of biodiversity and local environment. The collaborative efforts of ACAP and local people along with other actors have played crucial role to develop social facilities such as school, health post, electricity, drinking water, roads and telecommunication. About $97.6 \%$ respondents in AST agreed that social facilities and infrastructure have been improved now, which is $99.1 \%$ in MT, and $96.7 \%$ in OT. It is one of the most notable changes in the local communities brought by the ACAP and tourism development. Moreover, majority of respondents (90\%) also replied that tourism has increased their happiness and quality of life. Relatively, more respondents from MT (93.5\%) agreed with the statement than that of OT $(85.7 \%)$. On the other hand, despite its significant benefits to local residents, tourism has also been perceived as an agent to increase crime rate, and use of drug in the village. About $16.1 \%$ respondents in the AST agreed with this statement, though $48.2 \%$ disagreed and rests $(35.7 \%)$ were not sure. Relatively, more respondents from MT (18.5\%) agreed with the statement than that of OT (13.2\%). Some hoteliers also reported that there happened theft cases occasionally in their village, and the use of drug by the tourists, trek guides, porters and sometimes local people is also increasing. With these exceptions, local residents in general have perceived tourism as tool to improve their quality of life.

\section{Conclusion}

With regard to socio-cultural impacts, findings demonstrate that tourism has induced both positive and negative consequences on the local culture and social life. On one hand, social facilities and infrastructure such as road, school, health post, drinking water, and telecommunication have been improved in the settlements along the trail. On the other hand, local culture, traditions and architectural heritage have also been threatened by the tourism development. Indigenous culture has been exploited increasingly by the profit-driven tourism entrepreneurs. Evidences suggest that tourism is promoting the pursuit of modernity among indigenous communities in the AST, and it has created contradiction between the tourist's quest for authentic and exotic culture and the resident's desire for a modern life. One of the key reasons behind this situation is the lukewarm policies of cultural heritage conservation both tangible and intangible. Conservation of biodiversity is placed at the highest priority, with less attention towards cultural heritage. The lack of control on the construction of private buildings, and no specific attention on the vernacular architecture, and cultural practices has pushed communities towards crisis of cultural identity. In addition, lack of awareness and education about the cultural heritage conservation has further accelerated the degradation of local cultural 
resources and their authenticity. It is noteworthy to remember that better the implementation of conservation policies of local culture and heritage better will be the tourism situation that eventually benefits local communities. It is suggested that the ecotourism policies should therefore rigorously focus on the conservation of cultural heritage and community development together in the tourist destinations.

\section{References:}

- Ap, J. (1992). Residents' perceptions of tourism impacts. Annals of Tourism Research, 19 (4), 665-690

- Blamey, R. K. (2001). Principles of ecotourism. In D.B. Weaver (Ed.), The encyclopedia of ecotourism (pp.5-22). Oxon \& New York: CABI Publishing.

- Boo, E.(1993). Ecotourism planning in protected areas. In K. Lindberg and D. Hawkins (Eds.), Ecotourism: A guide for planners and managers (pp.15-54). North Bennington: The Ecotourism Society.

- $\quad$ Butler, R.W. (1990). Alternative tourism: Pious hope or Trojan horse? Journal of Travel Research, 28 (3), 40-45.

- Campbell, L. M. (1999). Ecotourism in rural developing countries. Annals of Tourism Research, 26, 531-553.

- Cater E. A. (1987).Tourism in the least developed countries. Annals of Tourism Research, 14,202-226.

- Ceballos-Lascurain, H. (1996). Tourism, ecotourism and protected areas: The state of nature-based tourism around the world and guidelines for its development. Gland, Switzerland and Cambridge, UK: International Union for Conservation of Nature (IUCN).

- $\quad$ Central Bureau of Statistics (CBS) (2012). "National Population and Housing Census 2011". Kathmandu: Central Bureau of Statistics.

- Chan, R. and Bhatta, K. D. (2013). Ecotourism planning and sustainable community development: Theoretical perspective for Nepal. South Asian Journal of Tourism and Heritage, 6(1), 69-96.

- $\quad$ Das, M. and Chatterjee, B.(2015). Ecotourism: A panacea or a predicament?. Tourism Management Perspectives, 14, 3-16.

- $\quad$ Dearden, P. (1991). Tourism and sustainable development in northern Thailand. Geographical Review, 81 (4), 400-413.

- deKadt, E. (1979). Tourism: Passport to development? Perspectives on the social and cultural effects of tourism in developing countries. New York: Oxford University Press.

- $\quad$ Diamantis, D. (2004). Ecotourism: Management and assessment. London: Thomson.

- $\quad$ Dogan, H. (1989). Forms of adjustment: Socio-cultural impacts of tourism. Annals of Tourism Research, 16 (2), $216-236$.

- Doxey, G.V. (1976). When enough's enough: The natives are restless in Old Niagara. Heritage Canada, 2 (2), $26-29$.

- Duffy, R. (2002). A trip too far: Ecotourism, politics and exploitation. London: Earthscan Publications Ltd.

- $\quad$ Eagles, P.F.J. (2001). Ecotourism impacts. In D.B. Weaver (Ed.), The encyclopedia of ecotourism (pp.359-362). Oxon and New York: CABI Publishing.

- $\quad$ Eagles P.F.J., Bowman, M.E., and Tao, T.C.H.( 2001). Guidelines for tourism in parks and protected areas of East Asia. World Conservation Union, World Commission on Protected Areas-East Asia Region, Gland, Switzerland.

- $\quad$ Fennell, D. A. and Eagles, P. (1990). Ecotourism in Costa Rica: A conceptual framework. Journal of Park and Recreation Administration, 8(1), 23-24.

- Fox, M. (1977). The social impact of tourism: A challenge to researchers and planners. In R.B. Finney and A. Watson (Eds.), A new kind of sugar: Tourism in the Pacific (pp.27-48). University of California, Santa Cruz, Centre for South Pacific Studies.

- Gurung, H. (1998). Sustainability and development in mountain tourism. In P.East, K.Luger and K.Inman (Eds.), Sustainability in mountain tourism (pp.29-45). Delhi: Book Faith India.

- Hall, C.M. and Lew, A. A.(Eds.). (1998). Sustainable tourism: A geographical perspective. Essex: Addison Wesley Longman Limited.

- Hatton, M.J. (1999). Community-based tourism in the Asia-pacific. Humber College. Toronto: APEC Publication.

- Honey, M. (1999). Ecotourism and sustainable development: Who owns paradise? Washington DC: Island Press.

- Inskeep, E. (1991). Tourism planning: An integrated and sustainable development approach. New York: Van Nostrand Reinhold.

- $\quad$ Kiss, A. (2004). Is community -based ecotourism a good use of biodiversity conservation funds? TRENDS in Ecology and Evolution, 19 (5).

- $\quad$ Lacher, R. G. and Nepal, S. K. (2010a).From leakages to linkages: Local-level strategies for capturing tourism revenue in northern Thailand. Tourism Geographies,12(1), 77-99.

- $\quad$ Lacher,R.G. and Nepal,S.K. (2010b). Dependancy and development in Northern Thailand. Annals of Tourism Research, 37 (4),947-968.

- Lee, C-K., and Back, K-J (2006). Examining structural relationships among perceived impact, benefit, and support for casino development based on 4 year longitudinal data. Tourism Management, 27 (3), 446-480.

- $\quad$ Lindberg,K., Anderson,T.D., and Dellaert, B.G.C.( 2001).Tourism development: Assessing social gains and losses. Annals of Tourism Research, 28(4), 1010-1030.

- $\quad$ Lindberg,K., Enriquez, J. and Sproule, K. (1996). Ecotourism questioned: Case studies from Belize. Annals of Tourism Research, 28(4), 1010-1030. 
- Lindberg, K. and Hawkins, D.E. (1993). Ecotourism: A guide for planners and managers. Washington ,D.C: The International Ecotourism Society.

- $\quad$ Lindberg, K. and Johnson, R. L. (1997). The economic values of tourism's social impacts. Annals of Tourism Research, 24 (1), 90-116.

- $\quad$ Liu, J. and Var, T. (1986). Resident attitudes toward tourism impacts in Hawaii. Annals of Tourism Research, 13 (2), $193-$ 214.

- Mathieson, A., and Wall, G. (1982). Tourism: Economic, Social and Physical impacts. Harlow: Longman.

- Milman, A. and Pizam, A. (1988). Social impacts of tourism on central Florida. Annals of Tourism Research, 15, $191-204$.

- Mitchell, R.E. and Reid,D.G. (2001).Community integration: Island tourism in Peru. Annals of Tourism research, 28 (1), 113-139.

- MoCTCA (2019). Nepal tourism statistics 2018. Kathmandu, Nepal: Ministry of Culture, Tourism and Civil Aviation (MoCTCA).

- MoCTCA (2011). Nepal tourism statistics 2010. Kathmandu, Nepal: Ministry of Culture, Tourism and Civil Aviation (MoCTCA).

- $\quad$ MoCTCA (2012). Nepal tourism statistics 2011. Kathmandu, Nepal: Ministry of Culture, Tourism and Civil Aviation (MoCTCA).

- Montes, J. and Kafley, B. (2019). Ecotourism discourses in Bhutan: contested perceptions and values, Tourism Geographies, DOI: 10.1080/14616688.2019.1618905

- $\quad$ Murphy, P. E. (1985). "Tourism: A community approach". London, UK: Methuen and Co. Ltd.

- Nepal, S.K. (2003). Tourism and the environment: Perspectives from the Nepal Himalaya. Lalitpur, Nepal: Himal Books.

- Nepal, S. K. (2000). Tourism in protected areas: The Nepalese Himalaya. Annals of Tourism Research, 27(3), 661-681.

- $\quad$ Norris, R. (1992). Can ecotourism save natural areas? National Parks,(Januray),22-34.

- $\quad$ NTNC (2009). Management plan of Annapurna Conservation Area 2009-2012. Kathmandu, Nepal: National Trust for Nature Conservation (NTNC).

- $\quad$ Nyaupane, G.P. and Thapa, B. (2004). Evaluation of ecotourism: A comparative assessment in the Annapurna Conservation Area Project, Nepal. Journal of Ecotourism, 3(1), 20-45.

- $\quad$ Orams, M.B. (1995). Towards a more desirable form of ecotourism. Tourism Management. 16(1).3-8.

- $\quad$ Pizam, A. and Milman, A. (1984). The social impacts of tourism. UNEP Industry and Environment, 7 (1), pp.11-14.

- $\quad$ Place, S. (1991). Nature tourism and rural development in Tortuguero. Annals of Tourism Research, 18, 186-201.

- $\quad$ Ross, S. and Wall, G. (1999). Ecotourism: Towards congruence between theory and practice. Tourism Management, 20(1), 123-132.

- Sharma, P.(1998). Sustainable tourism in the Hindu Kush- Himalaya: Issues and approaches. In P. East, K. Luger and K. Inmann (Eds.), Sustainability in mountain tourism: Perspectives for the Himalayan countries (pp.47-69). Delhi: Book Faith India.

- Slinger,V.(2000).Ecotourism in the last indigenous Caribbean community. Annals of Tourism Research, 27, 520-523.

- Smith,V. L. (1989). Introduction. In V.L. Smith (Ed.), Hosts and Guests: The anthropology of tourism (pp.1-17). Philadelphia: University of Pennsylvania Press.

- $\quad$ Stone, M. and Wall, G. (2003).Ecotourism and community development: case Studies from Hainan, China. Environmental Management, 33(1),12-24.

- $\quad$ Telfer, D. J., and Sharpley, R. (2008). "Tourism and development in the developing world". Oxon: Taylor and Francis.

- The International Ecotourism Society (TIES)(2015). What is ecotourism? Retrieved on $18^{\text {th }}$ September 2019, from website: https://ecotourism.org/what-is-ecotourism/

- $\quad$ Tourism Concern and WWF (1991). Beyond the green horizon. London: Roehampton Institute.

- United Nations' Economic and Social Commission for Asia and the Pacific (UNESCAP)(1999). Guidelines on integrated planning for sustainable tourism development. Retrieved on $20^{\text {th }}$ September 2016, website: http://www.unescap.org/publications/details.asp?id=818

- $\quad$ United Nations Environment Programme (UNEP) and World Tourism Organization (WTO)(2002). The Quebec declaration on ecotourism. UNEP and WTO.

- Wall, G. (1996). Ecotourism: Change, impacts and opportunities. In E. Malek-Zadeh (Ed.).The ecotourism equation: Measuring the impact (pp.206-216). New Haven: Yale School of Forestry and Environmental Studies.

- Wall, G. and Mathieson, A. (2006). Tourism change, impacts and opportunities. Toronto: Pearson Prentice Hall.

- Walpole, M. J. and Goodwin, H. J.(2001). Local attitudes towards conservation and tourism around Komodo National Park, Indonesia. Environmental Conservation, 28,160-166.

- Walpole, M. J. and Goodwin, H. J. (2000). Local economic impacts of dragon tourism in Indonesia. Annals of Tourism Research. 27, 559-576.

- Wearing, S. (2001). Exploring socio-cultural impacts on local communities. In D.B. Weaver (Ed.), The encyclopedia of ecotourism (pp.395-410). Oxon and New York; CABI Publishing.

- Weaver, D. B. (1998). Ecotourism in less developed world. Oxon: CAB International.

- Wight, P. (1994). Environmentally responsible marketing of tourism. In E. Cater and G. Lowman (Eds.), Ecotourism: A sustainable option? (pp.38-55). Chichester: John Willey \& Sons. 
- World Travel and Tourism Council (WTTC) (2019),Travel and tourism: Economic impacts 2019,Nepal. Retrived on 20 January, 2020, from the website: https://www.wttc.org/economic-impact/

- Ziffer, K. (1989). Ecotourism: An uneasy alliance, working paper no 1. Washington D.C.: Conservation International. 